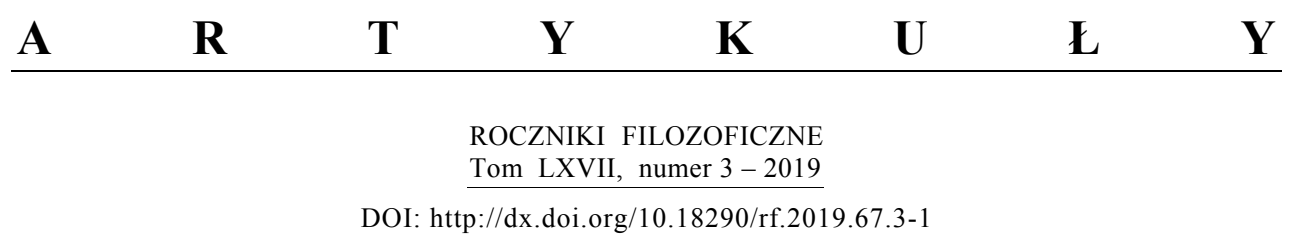

DARIUSZ DĄBEK

\title{
EDWARD A. MILNE'S PHILOSOPHY OF SCIENCE: BETWEEN ARISTOTELIANISM AND POPPERISM
}

\section{INTRODUCTION}

In the 1930s methodological debate, the main critic of rationalism in cosmology, represented by Arthur S. Eddington, Edward A. Milne, and Paul A.M. Dirac, was Herbert Dingle. His main question was: "Should we deduce particular conclusions from a priori general principles or derive general principles from observations?" (Dingle 1937a, 784). He considered the former a relapse into Aristotelianism and a betrayal of Galileo's method. The assumption of homogeneity of the Universe formulated as "cosmological principle" was the most objectionable aspect of Milne's cosmology, described by Dingle as "modern Aristotelianism" (Dingle 1937a, 786). He did admit that calling the cosmological rationalists "Aristotelians" did not imply that they agreed with Aristotle, but only that "they have revived the fallacy maintained by those whom Galileo and Newton called Aristotelians" (DingLE 1937b, 1011). Milne responded to Dingle's objections as follows:

One critic in particular has characterised my use of the cosmological principle as a lapse into Aristotelianism. I should indeed take it as a great compliment were I ever to be compared with Aristotle. [...] I used the notion of homogeneity - more accurately expressed as the cosmological principle - as a weapon for deducing what laws would hold good in a system satisfying it, thereafter comparing the laws deduced with the laws observed to hold good in our actual universe (MILNE 1952, 70-1).

Dr hab. DARIUSz DĄBEK - Katolicki Uniwersytet Lubelski Jana Pawła II, Wydział Filozofii, Instytut Filozofii, Katedra Filozofii Religii; adres do korespondencji: Aleje Racławickie 14, 20-950 Lublin; dabek@kul.pl; ORCID: https://orcid.org/0000-0002-4883-5133. 
The cosmological principle in Milne's Kinematic Relativity (KR) was used as a hypothesis. The conclusions were to be compared with the results of systematic observation to decide to accept or reject his theory. There are two questions about Milne's philosophy of science: 1) what aspects of Aristotle's conception of science can be found in Milne's philosophy; 2) how Milne's approach may have influenced Karl Popper's philosophy of science? These questions form the structure of this paper: first, we identify Milne's views that correspond to Aristotle's scientific method; second, those points of Milne's approach which are similar to Popper's hypothetism.

\section{MILNE'S ARISTOTELIANISM}

According to Aristotle, science should be universal, necessary and unchangeable knowledge that explains the essential features of reality by illuminating the causes of the observable facts. The three stages of Aristotelian scientific investigation are: 1) observation of phenomena leading to general principles 2) discovery of the most basic assumptions 3 ) deductive conclusions from these fundamental principles. The knowledge obtained is best seen as a deductive system containing two sets of statements connected by ties of apodictic (necessary) inference: the assumptions and the theorems deduced from them. The former have the status of self-evident and necessary principles in no need of proof; their ultimate source is experience and they are grasped by means of a "non-discursive intellectual operation called epagogé" (KAMIŃSKI 1992, 59). Aristotle's method of building a system of knowledge is characterised by three features: philosophical causalism (looking for the causes of the phenomena given for explanation), genetic empiricism (using experience to arrive at general principles, and not as a way of checking hypotheses), and deductionism (taking deductive reasoning as the chief element in the process of obtaining knowledge). An Aristotelian scientific theory is like a cone or pyramid: at the top are one or a few general principles from which more theorems would immediately be deduced, these would in turn serve as the basis for more deductions, and so on. Scientific theories should as far as possible be like axiomatic deductive systems (HAJDUK 2012b, 110). This immediately generates the question: which of the mentioned features of the Aristotelian approach were also adopted by Milne. 


\subsection{GAINING INSIGHT INTO PHENOMENA}

At a British Society session on 29 September 1931 (Dingle 1931) the thesis of the expansion of the Universe was accepted and the cause debated. One participant, J.H. James, said, that "we do not know, and probably shall never know why space is expanding" (Milne 1935, 3). This "scientific pessimism" prompted Milne's interest in cosmology. He knew the results obtained by V.M. Slipher and E. Hubble and was familiar with the first models of expanding Universe (MiLne 1933, 6-15). However, he believed that the explanation proposed by cosmology based on Einstein's General Relativity (GR) is philosophically unsatisfied. He attempted to find the cause, defining his purpose in a monograph published in 1935: "The investigations described here were an attempt to gain insight into the phenomenon of the expanding universe" (MiLne 1935, 1).

Milne repeatedly used the term "insight into phenomena" but did not define it precisely. He seems to have meant a certain postulated agreement between an imaginative interpretation of a theory and common sense (MILNE 1935, 3-4). This agreement with common sense makes for a certain similarity between Milne's philosophy of science and the Stagirite's conception, as "Aristotle wished to be comprehensible to all, to start from opinions shared by all and to keep as close as possible to 'common sense'" (BERTI $2015,278)$. P. Feyerabend also advocated the postulate of remaining close to common sense. In his opinion, Aristotelian science differs from modern science in its tendency to explain the world in terms of the perceived forms in which it appears rather than with another, presumably "deeper," reality (BERTi 2015, 264). This is also the attitude of Milne, who believed that "the mathematical physicist works with the world as it appears to be" (MILNE 1929b, 15).

Milne was a mathematician and astrophysicist, but saw himself primarily as a natural philosopher. He preferred to regard an observed phenomenon as illustrating some general theorem of mathematical physics rather than a solution to a particular problem. As his student W.H. McCrea remarked,

The challenge to him was not to solve the puzzle itself but to build up a system of theory which would naturally lead to the solution of some class of problems to which the particular one would be found to belong. [...] At the later stage he tended to the view that the more direct application of "philosophical" principles could lead to discovery of natural laws possessing a status superior to that of any hitherto known (MCCREA 1951, 429). 
Milne's purpose and way of working suggest that he saw the process of gaining insight into a phenomenon as a special kind of generalising explanation, tending to subsume observable phenomena under a general law. In the first phase of his cosmological investigations, Milne sought to explain the expansion of the Universe. Later he broadened his research, seeking general principles from which to deduce the whole of physics. This was essentially an Aristotelian attitude of discovering the essential features of investigated reality and understanding them as general principles from which to derive a principled scientific explanation. The question is how Milne went about discovering these general principles?

\subsection{FoRMULATING GENERAL PRINCIPLES}

Milne regarded the presuppositions in his theory as postulates, ${ }^{1}$ from which to deduce the greatest number of particular theorems. He made no use of inductively formulated natural laws in establishing these general principles. He asserted that selecting the most general principles of a physical theory is a matter of scientific inventiveness and not subject to pre-established rules. However, if the invented model is to describe the real world, it must be given an empirical interpretation and tested by comparing its predictions with the results of observation (MILNE 1929b, 26).

In searching for these general principles Milne preferred the inner to the outer experience. He relied on an inner observer's ability to assess the earlier-or-later relation between two events (Milne 1935, 14). Among the principles underlying his theory only the flow of time and the principle of causality were necessary and unalterable. The other assumptions were arbitrary and tentative hypotheses (DĄBEK 2011, 157). Milne's emphasis on the possibility of establishing these principles without reference to empirical data generated criticism of his investigative strategy by proponents of the inductive approach (LEPELTIER 2006, 476).

At first glance, Milne's way of identifying a theory's principal assumptions is quite different from Aristotle's, for whom observation of relevant phenomena guided the search for general principles. However, a closer look shows that his methodological declarations were often at odds with his research practice. In spite of his assurances to the contrary, he took account

\footnotetext{
${ }^{1}$ The complete list of the assumptions of Milne's theory is not readily available, as neither Milne himself nor his commentators present a unified account of that problem. See DĄBEK 2011, 59-61.
} 
from the outset of such empirically ascertained findings as the recession of galaxies, the interpretation of the cosmological redshift as an instance of the Doppler Effect, Hubble's law and the constant value of the speed of light (DA_BEK 2006). As he admitted, the idea of the substratum was suggested to him by the expanding universe (MiLne 1945, 140).

It is clear that he took account of current knowledge of the Universe, both theoretical and empirical. J. Jeans, one of Milne's critics, admitted in his debate with E. Whittaker that the principles accepted by Milne were not a priori principles but were in considerable measure a posteriori propositions, representing a condensed statement of a great number of observational data (GALE and SHANKS 1996, 291).

This research practice is close to the Aristotelian conception of the search for general principles being guided by the results of observation of phenomena. There is an essential difference, though, concerning a different epistemological status possessed by principles in Milne and in Aristotle. While for the Stagirite all principles possessed the characters of absolute certainty, necessity and self-evidence, in Milne only the two principles of the flow of time and of causality enjoyed such status. The rest of his assumptions were presuppositions arbitrarily selected to serve as axioms to construct a deductive system. This very special status of Milne's principles was highlighted by G. J. Whitrow, who pointed out that

[...] axioms are not "self-evident truths," but are definitions and statements qualifying subject-matter, which the theoretical investigator chooses freely. Provided that a set of axioms is logical, i.e. self-consistent and not redundant, the only other criterion it need satisfy is that it be fruitful (WhiтRow 1943, 299).

By this fruitfulness of an axiomatic system, Milne meant an agreement of that system, or of particular predictions derived from it, with the relevant results of observation.

\subsection{DEDUCING CONSEQUENCES FROM GENERAL PRINCIPLES}

With a definite set of basic assumptions, Milne could construct his system. He intended to achieve not so much derivation by deduction of a definite thesis related to what is to be explained (explanandum) as complete inference of all particular consequences entailed in the assumptions. Explaining the expansion of the Universe was the main objective only in the opening phase of Milne's investigations. The scope was expanded as he 
became aware how many statements corresponding to inductively grounded laws could be derived from a small set of presupposed principles, and in particular from the cosmological principle. To counter Dingle's objection of aristotelianism Milne wrote:

It is an astonishing thing that the elimination of other empirical appeals, including all appeals to quantitative laws of physics, can be carried out as far as it can, however imperfect the present state of the theory. No one has been more astonished than the present writer. [...] [W] hen we do thus eliminate such empirical appeals, regularities emerge (as logical consequences of the hypothesis) which play the part of the very laws of Nature which are observed to hold good (Milne 1937, 999).

Milne believed progress in natural sciences should consist, not in multiplying experiments and generalizing experimentally obtained results, but in reducing by deductive reasoning all these empirical results to few universal principles (MiLne 1935, 274). Scientific study of evolving nature should pass from mere inductively generalized laws to natural laws that would be equivalent to theorems deducible from a pre-established set of axioms (MILNE 1944, 11). This would enhance the epistemological status of physics, as such theorems, if in agreement with experience, would possess a higher degree of certainty than the laws that are merely inductive generalizations (MILNE $1941,364){ }^{2}$ Milne believed that physics should follow geometry in evolving from an empirical phase to a fully axiomatized system. ${ }^{3}$

Milne applied this top-down strategy of developing science as an ideal in his own scientific practice, with deduction of particular statements from universal assumptions as the most important element. He constructed not only his own cosmological model but also reconstructed a part of physics, namely kinematics, dynamics, gravity law and electromagnetism (Milne 1948).

This emphasis laid on deduction was a clear departure from the then dominant positivist methodology, and also a clear reference to the Aristotelian conception of science.

\footnotetext{
${ }^{2}$ It were so if there would be only one set of assumptions describing the global features of the Universe, from which the observable local properties would have to be deducible. See Heller 1978, 69 .

${ }^{3}$ Milne ignored the problem of finding out which of the known geometries actually describes the real Universe. He took it for granted that there was no physical space and he thought that for description of phenomena one can freely select a space defined by any geometry: "We can try to simplify laws of nature at the cost of complicating space, or simplify the space at the cost of complicating, or at least altering, the laws of nature" (MiLnE 1935, 13).
} 


\subsection{USING EMPIRICAL FACTOR}

In Aristotle's conception the empirical factor is the most important in the first phase of investigation. There are results of observation which move one to discover the nature of reality by pointing to the four causes: material, formal, efficient and final. The empirical factor is also present in the second phase of cognitive process, when intellectual intuition and empirical induction lead the mind to discover the first principles (HAJDUK 2012b, 136-7).

In Milne's philosophy of science the results of observation also generate a problem to be investigated. They prompt the attempt to gain an insight into phenomena and suggest the general assumptions. Milne was above all interested in discovering causal explanations of phenomena, not merely in registering natural regularities. He did not occupy himself with gathering observational data and generalizing results; however, he admitted that these results were an inspiration and helped him to determine the direction for his research:

Naturally, and legitimately the course of the various investigations has been guided and influenced by our knowledge of empirical science, but this is a totally different matter from making, in the course of deductions, specific empirical appeals, which are everywhere avoided (MILNE 1943, 74).

Unlike Aristotle, Milne held that empirical data should only be used in the final phase of the process of scientific investigation, namely in the empirical testing of the prepared model. This is the crucial point at which they provide the authoritative basis for the acceptance or rejection of the tested theory constructed as an axiomatic system. So, for Milne, the role of observation in scientific investigations was to test theories invented beforehand and formed into coherent axiomatic systems. First, observation would check if there exist in nature entities that exactly correspond to objects postulated by the axioms of the system. Second, it would help to establish whether the theorems derived from the axioms hold in the real world (MiLne 1937, 998).

The postulate to use results of observation mainly in the procedure of testing the empirical adequacy of a theory constructed as a deductive system seems to make for the most important difference between Aristotle and Milne. At the same time this postulate is one of the points that make Milne's theory close in some respects to that of K.R. Popper. 


\section{MILNE'S POPPERISM}

K.R. Popper's philosophy of science grew out of his criticism of logical empiricism, in particular the method of formulating hypotheses by inductive generalizations and the theory of confirmation as the way of testing these hypotheses. No scientific theory can be definitively verified by induction, as no general statement (law) can infallibly be justified by a finite set of particular statements. Rather than rely on uncertain inductive inferences, Popper proposed to use the logic of deduction. He focused on the fact that from general theoretical statements and particular conditions it is possible to derive infallibly certain propositions predicting occurrence of phenomena. These predictions can be tested by comparison with observational propositions. If the predictions do not agree with the observations, we may conclude that the general theoretical statement which served as the basis for these predictions is false too. ${ }^{4}$

The essential feature of Popper's scientific method is falsification: instead of looking for confirmations of scientific hypotheses, a scientist should try to overturn them through empirical testing. Failed attempts at abolishing a hypothesis lead to corroboration of that hypothesis and provide a reliable ground for accepting it. This approach defined a new strategy for scientific investigations. The starting point is no longer empirical data alone, rather it is provided by a new problem at the interface between experiences and hitherto accepted scientific knowledge. An attempt to solve this problem leads to tentative solutions which are subsequently subjected to testing. Whatever the result, it enlarges our comprehension of the investigated domain and points to new problems to be investigated. Progress in science is not achieved by cautious hypothesizing and seeking confirmation of already accepted theories, but by advancing bold, risky hypotheses and looking for instances that would overthrow them (HAJDUK 2012a, 69). This hypotheticaldeductionist strategy was already begun by H. Poincaré, P. Duhem and A. Einstein (TUREK 2009), developed by representatives of British rationalism, in particular by A. Eddington, P.A.M. Dirac and E.A. Milne, and was theoretically elaborated by K.R. Popper (GALE 1991).

\footnotetext{
${ }^{4}$ It is much more complex than indicated here, for example, by the problem of basis propositions, their theoretical content and the way of their acceptation. We limit ourselves to sketching Popper's main ideas in order to point out certain similarities between his philosophy of science and Milne's views.
} 


\subsection{ANTI-INDUCTIONISM}

Milne rejected the method of induction conceived as laborious gathering of experimental data and generalizing observed results to formulate hypotheses, establish laws and construct theories, as an inefficient scientific method. Milne saw the aim of science not so much to explain how nature functions, but to explain the regularities discovered by observation of nature. Induction as a method of carrying out this aim is useless.

Useful as the principle is for discovering regularities, useful as it is in inducing a personal belief in the future repetition of similar regularities, as a proposition it has no content. It sheds no light on the origin of laws of nature, on the reason for their simplicity, or on the fidelity with which they are obeyed. It is a piece of outmoded furniture, and in fundamental investigations it had better be scrapped (MiLne 1952, 31).

Milne pointed to the fact that induction fails to fulfil its heuristic function. The very conservative generalizing of results of empirical observations can at best produce very narrow hypotheses, which may capture certain regularities and describe the development of phenomena and processes, but which will never answer the most important question in science, the question concerning the very nature of these phenomena. Theorems that explain observations "will be discovered quite naturally by study of idealized models; they will never be discovered by explicitly seeking to account for observations" (MILNE 1929b, 27-8). Thus, bold hypotheses should be advanced and highly idealized models constructed which will give a possibility of comprehending the very nature of reality and the way of its functioning.

Milne laid particular emphasis on the shortcomings of the inductive method in the third period of his scientific activity, when he addressed the problems of cosmology. However, already before this period, when concerned with investigations into the constitution of stars and the processes within them, he was persuaded that observations alone and generalizing results of these observations are not enough for a meaningful insight into the object of enquiry.

It is not possible to infer from the observed masses, luminosities, and temperatures that the interiors of stars are necessarily composed of perfect gas; and that it is not possible to deduce the value of the absorption coefficient for the stellar interior. Instead, we are led to infer a single definite fact concerning the internal density distribution (MILNE 1929a, 17). 
According to Milne, the inductive method is of use in the process of formulating fundamental assumptions and postulating universal principles, as it reveals regularities ascertainable in nature, suggests problems for investigation, especially problems concerning causal explanations, guides us in our choice concerning the overall direction of inquiry. However, it is insufficient as a means of constructing theories and establishing laws.

The mathematician, in using the words "conjecture" or "hypothesis," emphasises the lack of sanction behind the routine when that routine is an experimentally-discovered arithmetical regularity; he feels its insecurity. The physicist exalts his similarly-discovered routine in a different field of phenomena by calling it a "law of nature," concealing of this term his reliance on some nebulous application of a Principle of Induction, and minimizing the lack of sanction behind it (MILNE 1941, 362).

Inductive generalizations are considerably inferior in status to theorems deductively derived from assumed principles. Therefore the right way to proceed is to construct theoretical models as axiomatic systems and then subject them to empirical testing in order to select the one that best describes and explains the observed facts.

\section{2. НypotheticAl DEDUCTIVISM}

In opposition to the inductionist approach, Milne believed that research in cosmology should start from general concepts that would fulfil the role of primary notions in the projected axiomatic system. These general notions referring to the macro-scale structure of the Universe e.g. the notion of "substratum" as a system, or "an equivalence" (MiLne 1941, 364) or "the world" as "the totality of the flux of events" that must appear the same to all observers (MILNE 1933, 3-4) determine a cosmologist's choice of basic assumptions and the formulation of hypotheses. According to Milne it was "a pioneer method, without which progress [of physical science] would be often slow or impossible" (Milne 1934, 20). However, in the eyes of proponents of inductionism these notions were wholly a priori in nature, depriving them and the whole deductive strategy of any value for cosmology.

In Milne's overall scheme of a complete scientific investigation one can identify four successive stages: 1) formulation of the problem and determination of the objective of the investigation, 2) selection of the basic assumptions (axioms) and primary notions, 3 ) construction of the theory by deducing the consequences of the accepted assumptions, 4) empirical testing 
of the completed theory. In the first two stages the cosmologist is not restrained by external rules: both the choice of the problem for investigation and the choice of primary assumptions and notions are a matter of his arbitrary decision. Results of experiments and the accepted background knowledge may at the very most inspire him and suggest certain ideas and not determine his choices. By contrast the scientist's efforts in the third stage are strictly determined by the rules of logic. The theorems obtained are true by virtue of the applied inferential procedures. Yet the question whether a correctly constructed theoretical model describes the real Universe is another matter. To answer this question one needs to apply empirical tests.

Milne repeatedly emphasised that in the process of construction of one's theory one ought not resort to any quantitative laws of nature, in particular to the ones arrived at as inductive generalizations.

We do not wish to assume laws of nature or take them for granted, or borrow them from experiment. We wish to infer, from the contents of the idealized universe, what would be the laws of nature in that universe (MILNE 1948, 5).

Most of the basic assumptions accepted in Milne's system were tentative hypotheses. One of the most important was the cosmological principle, which Milne borrowed from Einstein, to make it the chief axiom of his KR (MILNE 1937, 998). Critics of his methodology objected, that in selecting this assumption as central to his system in an a priori way, without a previous empirical test, he simply attempted to impose upon nature his own conception of what nature should be. However, he argued that the cosmological principle had been selected as one of the hypothetical assumptions of the constructed system which, in the case of a negative test, would have to be changed. One of Milne's followers, W.H. McCrea, drew attention to points of similarity existing between the KR and the theories of Newton and Einstein. He emphasised that

[...] the ultimate reason for belief in the "truth" of Newton's, or Einstein's, or Milne's laws of dynamics must be the same, namely agreement of the consequences of one theory or another, as a whole, with observation. The only difference is that Newton's theory makes the "laws" themselves the postulates (or hypotheses) of the theory, while Einstein's and Milne's theories deduce them from other postulates. In none of the cases are the "laws" either direct inductions from observation, or consequences of inescapable postulates (McCrea 1939, 154).

Milne's strategy on cosmology can be defined, on the one hand, as an attempt to axiomatize it, and on the other as a departure from the method 
dominant in positivism, of cautious formulating narrow hypotheses, arrived at by means of inductive generalizations. Instead of the bottom-up strategy of positivist orthodoxy, he advocates a top-down approach consisting in advancing bold hypotheses as universal principles, from which to deductively derive particular laws of nature. In the final analysis, the cognitive value of such a constructed, idealized model of the Universe, that is the answer to the question in what measure that model describes actual physical reality, will depend on the degree of agreement obtaining between predictions concerning empirical reality deducible from that model and the relevant results of observation as well as the hitherto approved physical knowledge. This emphasis upon hypotheses and deduction, which is a salient feature of Milne's methodology, is clearly a point of marked similarity between Milne's and K. R. Popper's philosophies of science.

\subsection{FALSIFICATIONISM}

Whether a given theoretical model can be considered an adequate description of the actual Universe depends on the degree to which it fulfils its cognitive purposes, in particular its explanatory and predictive functions. Milne's proposed procedure of testing hypotheses by comparing their predictions with actual observations appears to be closer to Popper's strategy of eliminating erroneous theoretical proposals than to the positivist method of seeking empirical confirmation for the formulated hypothesis (constructed theory).

The justification of this procedure must ultimately lie in whether it gives insight into observed features of the universe and in whether it predicts the existence of other observable features. It sets up a standard of comparison. If its predictions are not fulfilled, then the world as a whole will not satisfy the principle postulated, and we can start again with some other model (MiLne 1935, 171).

Empirical testing makes it possible to eliminate proposed theoretical models, which, although formally correct, are not proper descriptions of reality. Given the rigorous rules of deductive inference, any theoretical model which fails to conform to results obtained by means of experience, cannot be modified ad libitum to make it conform to the relevant results of observation. Thus, any model failing in its predictive functions must be discarded as a whole and a new set of basic assumptions compiled on which to construct a totally new theoretical model. This strategy of inquiry can be described as a trial and error strategy. It is far from the positivist inductive method and 
much closer to the Popperian procedure based on "conjectures and refutation," which in turn resembles the style of arguing applied in SocraticPlatonic and also in Aristotelian dialectic (BERTI 2015, 264).

Milne's falsificationism may have been inspired by Einstein's views (TUREK 2009). The author of GR, when comparing the inductive with the hypothetical-deductive method, came to emphasize the importance of intuition. With intuitive insight, a scientist can lay hold of the most essential feature of a set of facts and, consequently, formulate a hypothetical law. From that intuited law, he infers consequences that may be empirically tested and compares these consequences with the relevant results of experiments. Agreement of predictions derived from hypothetical assumptions with relevant empirical data legitimizes the previously assumed axioms and hypotheses, yet it cannot guarantee the truth of the theory. Any theory, however, can be definitively recognized as false on the strength of some internal criterion e.g. logical error or disproved on the basis of some external criterion e.g. disagreement between predictions and ascertainable facts (EINSTEIN 1919).

A similar program of conducting scientific research was put forward by Milne in 1929, when he was still concerning himself with astrophysics. Already at that stage he was critical of the method of induction and emphasized that experiments will never confirm our hypotheses, but sometimes they can disprove them. He elaborated this idea in a passage of his Inaugural Lecture at the University of Oxford, in which he attempted to define the purpose of theoretical astrophysics:

Its aim is to infer something of the real nature of the bodies observed. [...] The method of carrying out this aim is to suggest hypotheses and see if they predict results in agreement with observations. But I have already said that observation can never confirm our hypotheses, it can only disprove them. It is the prime business, then, of theoretical astrophysics to suggest not one hypothesis in any given field, but many. The duty of the theoretical astrophysicist is to construct models, and rigorously infer their properties. [...] It is of little importance in the first instance whether the models reproduce nature or not. A model which fails to reproduce nature is really more valuable than one which does - it at least shows what nature is not like, whilst a successful model leaves it an open question which of its characteristics is responsible for its success (MILNE 1929b, 25-6).

Proponents of inductionism objected to what they described as Milne's apriorism. Milne countered these objections by stressing the hypothetical (and not categorically assertive) nature of his chosen fundamental assumptions. Above all he pointed to concrete empirical tests which could falsify 
his theoretical model. He did not go so far as to make falsifiability the decisive criterion of value of hypotheses, laws and theories, but he appreciated negative results of the empirical testing of theoretical models fashioned by means of the hypothetical-deductive method. He pointed out that the negative results of empirical tests yield more certain knowledge than instances of agreement between theoretical predictions and the results of observations.

\subsection{LOGICAL RATIONALISM}

As mentioned, the main criticism of Milne's conception was his rationalism (as opposed to dogmatic empiricism) and in particular the possibility of formulating laws of nature in a purely rational way, without direct reference to experience, but instead by deduction from assumptions accepted a priori, independently of any observation. This, however, is not to be understood as an assertion of there being necessary synthetic a priori propositions because the ultimate test for the constructed axiomatic theoretical models was to be their agreement (or lack of it) with experience. Thus Whitrow can assert that attribution of apriorism to Milne is in fact groundless and "the most that can be justly claimed is that he tried to deduce laws similar to these [the fundamental laws of physics] from the postulates on which he had based his cosmology" (Whitrow 1993, 415).

Milne was fascinated with the logical precision of deductive axiomatic systems, which on the one hand inspired his conviction that physics needs to be fully axiomatized, but on the other made him exaggerate the purely rational (a priori) nature of the grounds for the choice of fundamental assumptions as the axioms of the constructed system. This purely rational approach was not borne out by his own practice as a theorist, as, despite his assurances, most of the principles assumed to form the axiomatic basis of his KR either followed directly from results obtained by observation or were otherwise clearly related to some sections of the established physical theory. Perhaps the status of the cosmological principle, which was the main assumption of his theory, can be regarded as somewhat exceptional (LEPELTIER 2006, 477). Yet even that assumption was not entirely novel, as it had already functioned in GR and in the models of relativist cosmology.

Thus one can hardly agree with H. Kragh's opinion that empirical knowledge played only an insignificant role in KR (KRAGH 1996, 64). As has been shown, Milne's emphasis on the purely rational (non-empirical) grounds for 
the selection of the basic assumptions of a physical theory and on the logical precision of inferences within that theory did not mean disregarding or marginalizing experience in practice. Nor can one readily agree with T. Lepeltier's opinion that "a clear distinction has to be made between an attraction towards a highly axiomatized theory, such as general theory of relativity, and an attraction towards a theory deduced from general principles that have no link with observation, such as kinematic relativity" (LEPELTIER 2006, 479). Both GR and KR were highly axiomatized, both theories were constructed by means of the hypothetical-deductive method, both contained assumptions strictly related to empirical knowledge (e.g. constant speed of light in a vacuum) as well as postulates purely hypothetical in nature (e.g. the cosmological principle). The authors of both theories were convinced of the inherent rationality of nature and of the efficacy of the principles of logic and pure mathematics in the process of bringing to light the way of nature's functioning. ${ }^{5}$ It was precisely this belief that made Milne assert that physics as a science can and should develop towards total axiomatization (MILNE 1941, 365).

It follows from a careful analysis of Milne's epistemological and methodological views, that he can be qualified as a proponent of rationalism only in a certain restricted sense. The main feature of his rationalism is neither intuition as a source of true knowledge, nor existence of innate knowledge and innate concepts gained a priori, regardless of experience (MARKIE 2017). It is rather a belief in the power and unquestionable character of the laws of logic. Such a form of rationalism may be called logical rationalism. As already noted, many features of Milne's views are similar to Popper's critical rationalism. Both assumed that rationality and objectivity of science ought to rest on two crucial factors: the use of the rules of deductive logic and rigorous empirical testing of formulated hypotheses. In the process of formulating hypotheses the crucial role is played by creative invention of the scientist, yet the final decision as to the cognitive value of these hypotheses depends on their agreement with experience. Negative result of the empirical testing of theoretical results is the source of more certain knowledge than empirical confirmation of hypotheses. The scheme of the process of investigation as recommended by Milne is very much like the scheme advocated by

\footnotetext{
5 "Our experience up to date justifies us in feeling sure that in Nature is actualized the ideal of mathematical simplicity. It is my conviction that pure mathematical construction enables us to discover the concepts and the laws connecting them which give us the key to the understanding of the phenomena of Nature" (EINSTEIN 1934, 167).
} 
Popper: 1) formulation of a problem for investigation, 2) choice of hypothetical assumptions and construction of a deductive system based thereon, 3) empirical testing of predictions derived from the system, 4) elimination of the theoretical models that fail to conform to experience and (provisional) acceptation of those whose predictions have been borne out by relevant results of observation. The idea of deductive explanation in science, the most prominent feature of Popper's philosophy of science, was already formulated in Milne's conception and identified as one of the chief objectives of scientific investigative process.

\section{CONCLUSIONS}

Milne's philosophy of science was largely consonant with Aristotle's conception of scientific knowledge and the way it is earned. The purpose of science is to obtain an explanation of the way nature works that is in agreement with common sense and discovering universal laws and principles that govern nature's operations. The most important feature of the strategy of investigation is deductive derivation of statements capturing regularities in nature from the assumed principles. These initial and fundamental assumptions are formulated as a result of the scientist's reasoning and creative invention, yet the choice of the actual set of principles is also guided by relevant results of observation and the hitherto acquired knowledge of nature's laws. In contrast to Aristotle's system, however, most of Milne's assumptions are hypothetical in nature and their affirmation ultimately depends on the results of empirical testing. For Milne, only two of the accepted principles are really indubitable: the flow of time and the principle of causality.

Such a conception not only realizes Aristotle's leading postulates as to scientific knowledge, it is also in agreement with Einstein's investigative practice, which in turn prepared the way for the Popperian hypothetism. According to Milne, induction does not lead to acquisition of well-grounded knowledge (experiments will never confirm our hypotheses, but sometimes they can disprove them), yet it is not without value, since it indicates problems for exploration, provides suggestions as to the selection of the body of basic assumptions, and, in the final stage, helps to identify the theories (models) that fare best in the task of explaining reality. The really efficient way to fulfil the objectives of science (explanation and prediction) is the 
hypothetical-deductive method. Comprehension and creative invention (of the scientist) are the main resources on which to draw in formulating primary universal principles which should take the form of bold hypotheses, while the logical rules of deductive inference provide the basis for derivation of particular statements capturing regularities in nature and ensure infallibility of the discursive element of the procedures of investigation.

\section{ACKNOWLEDGMENTS}

I would like to thank Roman Majeran and John Adshead for providing language help and proof reading the article. This research did not receive any specific grant from funding agencies in the public, commercial, or notfor-profit sectors.

\section{REFERENCES}

Berti, Enrico. 2015. Arystoteles w XX wieku. Translated by Anna Dudzińska-Facca \& Danilo Facca. Warszawa: Wydawnictwo Instytutu Filozofii i Socjologii Polskiej Akademii Nauk.

DĄBEK, Dariusz. 2006. "Czynnik empiryczny w kosmologii Edwarda Artura Milne'a.” Roczniki Filozoficzne 54, 2: 31-47. http://www.jstor.org/stable/43409837.

DĄBEK, Dariusz. 2011. Kosmologia Edwarda Artura Milne'a i jej filozoficzne implikacje. Lublin: Wydawnictwo KUL.

DingLE, Herbert. 1931. "The Evolution of the Universe." Nature 128, 3234: 699-722. DOI: 10.1038/128699a0.

DingLE, Herbert. 1937a. "Modern Aristotelianism." Nature 139, 3523: 784-6. DOI: 10.1038/ $139784 \mathrm{a} 0$.

Dingle, Herbert. 1937b. "Deductive and Inductive Methods in Science: A Reply." Nature 139, 3528: 1011-14. DOI: 10.1038/1391011a0.

EInSTEIN, Albert. 1919. "Induktion und Deduktion in der Physik." Berliner Tageblatt und Handelszeitung 25, Suppl 4: 1.

Einstein, Albert. 1934. "On the Method of Theoretical Physics." Philosophy of Science 1, 2: 163-9. http://www.jstor.org/stable/184387.

GALE, George. 1991. "Rationalist programmes in early modern cosmology." Astronomy Quarterly 8, 4: 193-218. DOI: 10.1016/0364-9229(91)90002-3.

Gale, George, and Niall ShanKs. 1996. "Methodology and the birth of modern cosmological inquiry." Studies in History and Philosophy of Modern Physics 27, 3: 279-96. DOI: 10.1016/S1355-2198(96)00008-1.

HAJDUK, Zygmunt. 2012a. Filozofia nauk przyrodniczych. Lublin: Wydawnictwo KUL.

HAJDUK, Zygmunt. 2012b. Ogólna metodologia nauk. $6^{\text {th }}$ ed. Lublin: Wydawnictwo KUL.

Heller, Michał. 1978. "Uwagi o metodologii kosmologii." Roczniki Filozoficzne 26, 3: 65-75. http://www.jstor.org/stable/43409547.

KAMIŃSKI, Stanisław. 1992. Nauka i metoda: Pojęcie nauki i klasyfikacja nauk. Lublin: Towarzystwo Naukowe Katolickiego Uniwersytetu Lubelskiego. 
Kragh, Helge. 1996. Cosmology and controversy: The historical development of two theories of the universe. Princeton: Princeton University Press.

LePELTiER, Thomas. 2006. "Edward Milne's influence on modern cosmology." Annals of Science 63, 4: 471-81. DOI: 10.1080/00033790600718578.

MARKIE, Peter. 2017. "Rationalism vs. Empiricism." In The Stanford Encyclopedia of Philosophy (Fall 2017 ed.), edited by Edward N. Zalta. https://plato.stanford.edu/archives/fall2017/ entries/rationalism-empiricism/ (10.04.2018).

MCCrEA, William H. 1939. "The Evolution of Theories of Space-Time and Mechanics." Philosophy of Science 6, 2: 137-62. DOI: 10.1086/286542.

MCCreA, William H. 1951. "Edward Arthur Milne, 1896-1950." Obituary Notices of Fellows of the Royal Society 7, 20: 420-43. DOI: 10.1098/rsbm.1951.0010.

Milne, Edward A. 1929a. "The Masses, Luminosities, and Effective Temperatures of the Stars." Monthly Notices of the Royal Astronomical Society 90, 1: 17-54. DOI: 10.1093/mnras/ 90.1.17.

Milne, Edward A. 1929b. The Aims of Mathematical Physics: An Inaugural Lecture delivered before the University of Oxford on 19 November 1929. Oxford: Clarendon Press.

Milne, Edward A. 1933. "World-Structure and the Expansion of the Universe." Zeitschrift für Astrophysik 6: 1-95. http://adsabs.harvard.edu/abs/1933ZA.....6....1M.

Milne, Edward A. 1934. "Some Points in the Philosophy of Physics: Time, Evolution and Creation." Philosophy 9, 33: 19-38. DOI: 10.1017/S0031819100030564.

MiLnE, Edward A. 1935. Relativity, gravitation and world-structure. Oxford: Clarendon Press.

Milne, Edward A. 1937. "On the Origin of Laws of Nature." Nature 139, 3528: 997-9. DOI: $10.1038 / 139997 \mathrm{a} 0$.

Milne, Edward A. 1941. "Remarks on the Philosophical Status of Physics." Philosophy 16, 64: 356-71. DOI: 10.1017/S0031819100002795.

MiLne, Edward A. 1943. "Rational electrodynamics.-I. The limitations of classical electromagnetism." Philosophical Magazine and Journal of Science 34, 229: 73-82. DOI: 10.1080/14786444308520829.

Milne, Edward A. 1944. "The Fundamental Concepts of Natural Philosophy." Proceedings of the Royal Society of Edinburgh. Section A. Mathematical and Physical Sciences 62, 1: 10-24. DOI: $10.1017 / \mathrm{S} 0080454100006361$.

Milne, Edward A. 1945. "Kinematic relativity: A reply to Prof. W. Wilson." The London, Edinburgh, and Dublin Philosophical Magazine and Journal of Science 36, 253: 134-143. DOI: 10.1080/14786444508520911.

Milne, Edward A. 1948. Kinematic relativity: A sequel to relativity, gravitation and world structure. Oxford: Clarendon Press.

Milne, Edward A. 1952. Modern cosmology and the Christian idea of God, Oxford: Clarendon Press.

TUREK, Józef. 2009. “Albert Einstein prekursorem hipotetyzmu Karla Poppera.” In Wokót Einsteina. Dylematy filozofów i fizyków, edited by Zdzisław Błaszczak and Antoni Szczuciński, 173-88. Poznań: Wydawnictwo Naukowe Uniwersytetu im. Adama Mickiewicza w Poznaniu.

Whitrow, Gerald J. 1943. "Axiomatic Treatment of Kinematical Relativity: A Reply to Dr G.C. McVittie." Proceedings of the Royal Society of Edinburgh. Section A: Mathematics 61, 3: 298-99. DOI: 10.1017/S0080454100006300.

Whitrow, Gerald J. 1993. "Milne's Cosmology." In Encyclopedia of Cosmology: Historical, Philosophical, and Scientific Foundations of Modern Cosmology, edited by Norriss S. Hetherington, 410-16. New York: Garland Publishing. 


\section{FILOZOFIA NAUKI EDWARDA A. MILNE'A: MIĘDZY ARYSTOTELIZMEM A POPPERYZMEM}

$$
\text { Streszczenie }
$$

Artykuł jest próbą wykazania, że E.A. Milne’a filozofia nauki ma swoje źródła w filozofii Arystotelesa i mogła stanowić inspirację dla Popperowskiego hipotetyzmu. O zgodności z koncepcją Arystotelesa świadczą następujące jej cechy: 1) celem nauki jest wyjaśnianie zjawisk przez odkrywanie ogólnych zasad; 2) istotną rolę w ich odkrywaniu spełnia umysł, choć doświadczenie ukierunkowuje poszukiwania; 3) dedukowanie szczegółowych twierdzeń z ogólnych założeń jest najważniejszym elementem badań. Z drugiej strony propozycja Milne'a jest zgodna z głównymi ideami koncepcji Poppera: 1) krytyką zasady indukcji; 2) preferowaniem metody hipotetyczno-dedukcyjnej (założenia mają charakter śmiałych hipotez i są akceptowane na podstawie wyników testów empirycznych); 3) docenieniem falsyfikacji i przekonaniem o skuteczności logiki dedukcyjnej.

\section{EDWARD A. MILNE'S PHILOSOPHY OF SCIENCE: BETWEEN ARISTOTELIANISM AND POPPERISM}

\section{S u m m a ry}

This article seeks to show that E.A. Milne's philosophy of science has its roots in the philosophy of Aristotle and it could be an inspiration for Popper's philosophy. The similarities with Aristotle's concept are as follows: 1) the aim of science is to explain phenomena by discovering general principles; 2) the mind is responsible for discovering them, although experience guides the search; 3) deducing detailed statements from general assumptions is the most important element of research. On the other hand, Milne's proposal is consistent with Popper's main ideas: 1) criticism of the principle of induction; 2) preference for the hypothetical-deductive method (assumptions should be bold hypotheses that require empirical testing to be accepted); 3) appreciation of falsification and confidence in the effectiveness of deductive logic.

Słowa kluczowe: E.A. Milne; kinematyczna teoria względności; filozofia nauki; Arystoteles; K.R. Popper

Key words: E.A. Milne; Kinematical Relativity; Philosophy of Science; Aristotle; K.R. Popper.

Information about Author: Dr. hab. DARIUSZ DĄBEK - the John Paul II Catholic University of Lublin, Faculty of Philosophy, Institute of Philosophy, Department of the Philosophy of Religion; address for correspondence: Aleje Racławickie 14, 20-950 Lublin; dabek@kul.pl; ORCID: https://orcid.org/0000-0002-4883-5133. 